\title{
CURRENT STATUS OF RESEARCH ON THE STEM BLEEDING DISEASE OF COCONUT IN INDIA
}

\author{
By \\ KKN NAMBIAR and ROHINI IYER ${ }^{1}$
}

\section{INTRODUCTION}

Stem bleeding disease of coconut was reported from India in 1922 by Sundaraman. Earlier Petch (1906) had reported the disease from Sri Lanka. Now the disease is known to occur in many coconut growing countries (Ohler, 1984).

\section{Symptoms:}

The disease is characterized by the appearance of dark brown streaks or patches along the stem cracks towards the base of the tree. A dark reddish brown liquid exudes from the growth cracks. Adjacent patches may coalesce to form large patches. Often the exudation is found dry. The external symptoms do not often betray the extent of internal decay. On chiselling away the bark, it can be seen that the lesions do not penetrate beyond $2-3 \mathrm{~cm}$ in depth. Symptoms are severe in young palms where the bark decays leaving only fibrous tissues. Upon puncturing the discolored bark, a dark liquid gushes out. These symptorns, in general, are aggravated by cool weather, sometimes even leading to the decay of inner tissues.

As the disease becomes chronic, the patches begin to appear higher and higher up on the stem. Changes become perceptible in the crown by now. Reduction in the size of leaves and consequent reduction in the size of the crown, and shedding of buttons and immature nuts also follow. Severely affected trees have tapered trunks. Finally, the leaves also dry gradually leaving a headless tree.

A method for inclexing the disease severity in stem bleeding affected coconut palms based on lesion size and the score for tapering was developed by Mathew et al. (1989) at the Central Plantation Crops Research Institute. The inclex can be worked out using the formula $\mathrm{I}=1.81=4.3 \mathrm{t}$ where ' 1 ' is the lesion size expressed in $1,000 \mathrm{cms}^{2}$ and $\mathrm{t}$ is the score for tapering (on a $0-4$ scale). The index developed has a range of $0-100$. The index so calculated was evaluated under field conclitions and was found to be very useful.

\section{Etiology:}

Observations of Petch (1908) that T. paradoxa incites the disease by infecting wound sites, have been confirmed by Nambiar et al. (1986) when artificial inoculations using T. paradox isolated from diseased palms from Kasaragod (Kerala), Appangala (Coorg district, Karnataka State) and Vittal (Kamataka State) produced disease symptorns on healthy palms in the respective locations. Inoculum was multiplied on sterilized rachilla bits or petioles of Cyperussp. (umbrella grass). Characteristic rusty brown discoloration of the bark was noticed around the inoculated sites within 2-8 weeks depending on the location. Copius gushing of brown liquid was noticed on palms at Appangala, coolest among the places. The gummy exudates contained conidia of $T$. paradoxa.

\footnotetext{
${ }^{1}$ Head, Division of crop Protection and Scientist, respectively, Central Plantation Crops Research Institute, India
} 


\section{Isolation technique:}

For all such studies, the method developed by Anil Kumar and Nambiar (Anon, 1989) for isolating T. paradoxa from infected tissue was used. This simple and highly reproducible method makes use of frond tissue from the lower whorls of coconut palm. The method consists of inoculation of the frond pieces by bore hole method, incubation in polythene bags at $30^{\circ} \mathrm{C}$ for 10 days and isolation of the fungus from the margin of lesions on to sugarcane juice agar.

Similarly, Anil Kumar and Nambiar (Anon., 1990) made use of sterile bits of frond tissue as baits to recover T. paradoxa from infected soils. Here, the test soil is air dried and is sieved through a $2 \mathrm{~mm}$ sieve. In a sterile $100 \mathrm{~mm}$ petridish, $50 \mathrm{~g}$ of the soil is taken and to this $5 \mathrm{ml}$ sterile water is added. Ten pieces of $(0.5 \times 0.5 \times 1.5 \mathrm{~cm})$ coconut leaf frond tissue pieces are kept and the plates are incubated at $30^{\circ} \mathrm{C}$ for $48 \mathrm{hr}$. The baits are then recovered and washed throughly. A thin sliver of the tissue is removed from all the six sides of the bait and the baits are kept on sugarcane juice agar. After $48 \mathrm{hr}$ of incubation, the number of baits showing growth of T. paradoxa is used as an index to quantify the $T$. paradoxa propagules in soil, based on a standard curve.

\section{Epidermiology:}

Nambiar et al. (1989) studied the effect of season on infection by $T$. paradoxa by artificial inoculation trials conducted from April to November. The maximum lesion depth/size was recorded in palms inoculated during or after monsoon (July to November). The lesion size was comparatively less in palms inoculated during April-May. Young WCT palms (10-12 yrs) showed more internal decay as compared to 45-60 yr old palms. The infection was low or delayed during summer months. High humidity and moderate temperature might have favoured the disease development from July toNovember while reduced moisture and high temperature might have affected the April-May inoculations (Table 1).

Table 1: Lesion dimension in coconut stem of different ages, inoculated with Thielaviopsis Paradoxa during different months (after Nambiar et al., 1989)

\begin{tabular}{|l|l|c|c|c|c|c|}
\hline \multirow{2}{*}{$\begin{array}{c}\text { Date of } \\
\text { inoculation }\end{array}$} & \multicolumn{3}{|c|}{ Palms of 10-20 years } & \multicolumn{3}{c|}{ Palms of 45-60 years } \\
\cline { 2 - 7 } & $\begin{array}{c}\text { Duration } \\
\text { of first symptoms } \\
\text { (month) }\end{array}$ & $\begin{array}{c}\text { Lession } \\
\text { depth } \\
(\mathrm{cm})\end{array}$ & $\begin{array}{c}\text { Lession } \\
\text { size } \\
(\mathrm{cm})\end{array}$ & $\begin{array}{c}\text { Duration } \\
\text { for appearance } \\
\text { of first symptoms } \\
\text { (months) }\end{array}$ & $\begin{array}{c}\text { Lession } \\
\text { depth } \\
(\mathrm{cm})\end{array}$ & $\begin{array}{c}\text { Lession } \\
\text { size } \\
(\mathrm{cm})\end{array}$ \\
\hline Nov. '85 & Not inoculated & - & - & 1.8 & 4.5 & $10.3 \times 2.6$ \\
April '86 & Do & - & - & Nil & Nil & Nil \\
May '86 & 6 & 2.8 & $4 \times 2.3$ & 7 & 1.3 & $3.7 \times 2.5$ \\
July '86 & 2 & 2.3 & $7 \times 2.5$ & 2 & 4.3 & $6 \times 3$ \\
Sept. '86 & 2 & 4.5 & $6 \times 2.3$ & Not inoculated & & \\
Nov. '86 & 2 & 7.0 & $6 \times 2.0$ & 2.3 & 3.5 & $8 \times 3.5$ \\
April '87 & 6.5 & 2.3 & $3.5 \times 2.1$ & Not inoculated & & \\
July '87 & 2 & 3.0 & $3.3 \times 2.3$ & 2.3 & 3.5 & $3.5 \times 2.3$ \\
\hline
\end{tabular}

Observations were taken Dec. '87

Radhakrishnan (1987) also observed that maximum symptorns were seen in July under red laterite-loam conditions at Pilicode (Kerala), and the least in surnmer months in irrigated palms growing in sandy-loam soils at Nileshwar (Kerala). According to him, the disease first makes its appearance during the period of September to November. 
Potty and Radhakrishnan (1978) reported that incidence of stem bleeding was more when soil nitrogen supply was deficient or phosphorus availability was in excess. According to them unbalanced fertilization leading to disturbed physiological condition of the palms was the cause of the disease.

Mathew and Ramanandan (1980) studied incidence of stem bleeding discase in relation to $\mathrm{pH}$ and electrical conductivity (EC) of soils at sixteen locations spread out in Kerala, Karnataka, Goa and Tamil Nadu. They found that the EC was less than one millimhos in samples collected from both healthy and disease affected gardens. Only in two locations, namely Kumarakom (Kerala) and Uchipuli (Tamil Nadu) the EC was significantly more in soils of healthy palms than in soils from the diseased garden. In all the other places there was no significant difference. The $\mathrm{pH}$ values showed that even though they varied from place to place, no appreciable difference between healthy and diseased areas could be noticed. They concluded that soil reaction and electrical conductivity do not influence the incidence of stem bleeding disease in coconut. Nagarajan (1985) reported that excessive salinity with high sodium during surnmer is associated with the disease.

In addition to the damage caused by fungal infection the watersoaked bark is often affected by scoletid beetles who bore pin-holes into the stem and slowly encourage penetration of decay deep into the stem. The symptorns arc more pronounced during surnmer. Crown symptorns arc more alleviated by irrigation and mitigation of drought (Nambiar and Sastry, 1988).

Studies had been taken up on the survival of inoculum of T. paradoxa in soil under various conditions by Usman (1988). He studied the survival of T. paradoxa in three different types of soil; namely, sandy, laterite and red loam in three depths. namely, 5, 15 and $30 \mathrm{cms}$., and also under different treatments; namely, amended with neem cake, cowdung, protected with a cover crop of Mimosa invisa and Calapogonium mucunoides.

Observations on the chlarnydosporle germination taken at various intervals showe-d that chlarnydospore germination was, the least in top soil, irrespective of soil types studied. Germination was, least in sandy soil at all depths. Enhanced chlarnydospore germination was noticed in laterite soil. Maximum survival (53\%) was seen in red loam. In the case of neem cake amended soil, the survival of chlamydospores was minimum. In the case of soils where cover crops were grown, the chlarnydospore germination was higher as compared to other treatments-probably because of the insulating effect of the cover crops against direct radiation and also due to the availability of soil moisture. The germination of chlarnydospore was greatly affected at $40^{\circ} \mathrm{C}$ and above.

\section{Variability:}

The variability existing among the different isolates of $T$. paradoxa has been observed as a part of epiderniology studies. Gowda (1987) isolated T. paradoxa from various sources like bark, soil, nut etc. from different locations in Kerala and Karnataka. He observed a wide variability among isolates of T. paradoxa with regard to characters like color, nature of colony, pattern of growth in various media, conidia, and chlarnydospore production, reaction towards antagonistic fungi etc. Further work on variability of fourteen isolates of $T$. paradoxa originating from different parts of Kerala and Karnataka was undetaken by Nishita Naik (1990) who found that among natural media, sugarcane juice agar supported good growth and sporulation of the fungus and among the synthetic media tried, dextrose-asparagine-phosphate agar was found to be the best. Some of the isolates also emitted a characteristic fruity smell (pineapple type). The isolates expressed wide variability with regard to their requirement of temperature $\mathrm{pH}$, carbon, and nitrogen sources. Optimum temperature for growth was, found to be $30^{\circ} \mathrm{C}$ and $\mathrm{pH} 5.5$ was, found to be optimum. While xylose supported the best growth of ail isolates, the best nitrogen source was asparagin. Here also a few isolates preferred inorganic sources like potassium nitrate. When media were supplemented with vitamins the spore production was enhanced, even though they had no influence on the vegetative growth. Ail isolates 
were completely inhibited in vitro at $10 \mathrm{ppm}$ cone. by Bavistin (carbendazim) and calixin (Tridemorph). However, Dithane M-45 (Mancozeb), Vitavax (carboxin), and Aureofungin-sol inhibited the fungal growth only at the very high concentration of $10,000 \mathrm{ppm}$.

\section{Disease management:}

Ever since this disease was described from India, Sundararaman (1922) had prescribed removai of affected bark tissue and painting the trunk with hot coal tar. This measure is even now practised with limited success. The use of systemic fungicides like Calixin, Bavistin, and Aureofungin-sol, and organic amendments like neem-cake were also tried by various workers. At Pilicode, Kerala, a field trial involving systemic fungicides like Bavistin, Calixin, Benlate, Vitavax and Aureofungin-sol, and Bordeaux mixture + neem cake, and coal tar application was in progress during t984-87 period. The treatments were applied once in two months to the experimental palms. The systemic fungicides except Aureofungin-sol was applied through stem injection (Radhakrishnan, 1990). At the end of four years, calixin was found to be superior in alleviating the disease incidence (Table 2). Bavistin, Benlate, Vitavax, coal tar application and neem cake + Bordeax treatment were on par. Coal tar application and aureofungin-sol were also on par.

Table 2: Transformed values of increase in percentage infection of stem bleeding disease incidence (Radhakrishnan, 1990)

\begin{tabular}{|c|c|c|c|c|c|}
\hline & 1984 & 1985 & 1986 & 1987 & Mean \\
\hline $\mathrm{T}_{1}$ & 1.26 & 1.32 & 1.16 & 0.95 & 1.17 \\
$\mathrm{~T}_{2}$ & 0.58 & 0.43 & 0.10 & 0.95 & 0.51 \\
$\mathrm{~T}_{3}$ & 0.91 & 1.45 & 0.86 & 1.68 & 1.22 \\
$\mathrm{~T}_{4}$ & 0.91 & 1.21 & 1.15 & 1.36 & 1.16 \\
$\mathrm{~T}_{5}$ & 1.06 & 1.42 & 1.65 & 0.78 & 1.23 \\
$\mathrm{~T}_{6}$ & 1.87 & 2.28 & 1.37 & 1.24 & 1.69 \\
$\mathrm{~T}_{7}$ & 1.34 & 1.01 & 0.76 & 1.00 & 1.03 \\
${ } }$ & & & & & 1.14 \\
\hline
\end{tabular}

SE of Means $=0.1681$

$\mathrm{CD}=0.499$

Field trials were conducted by CPCRI during 1986-89 (Anon, 1990) at three different locations using four systemic fungicides, namely Bavistin, Calixin, Aureofungin sol and Vitavax through root feeding thrice a year. These fungicides were applied at the rate of $0.5 \mathrm{~g}$ or $0.5 \mathrm{ml} / \mathrm{palm}$. Among the treatments, Calixin followed by Bavistin were found to be more efficient in the disease management (Table 3).

Anil Kumar and Nambiar (Anon, 1989) analysed the residues of MBC, the active ingredient in Bavistin, in stem tissues and tender-nut water. Samples collected at different intervals from varying heights and different sides of the palm trunk were used for detection of the chernical using bioassay. MBC was detected upto 1 meter height along the feeding side upto 20 days when palms were treated with $0.5 \mathrm{~g}$ Bavistin through root feeding (Table 4). The fungicide was detected upto $2 \mathrm{M}$ height in samples taken from feeding side upto 120 days when palms were rootfed @ $5.0 \mathrm{~g}$ MBC (10.0 g Bavistin)/palm. No fungicide was detected in the remaining samples. This seems to suggest that there is very little lateral movernent of Bavistin in the coconut stem. In nut water, no residue was detected after 23 days of treatment. 
Table 3. Effect of different fungicidal treatments on stem bleeding disease of coconut (Anon. 1990)

\begin{tabular}{|l|c|c|}
\hline \multicolumn{1}{|c|}{ Treatments } & $\begin{array}{c}\text { \% increase (+) or decrease (-) } \\
\text { in disease index }\end{array}$ & $\begin{array}{c}\text { \% increase (+) or decrease } \\
(-) \text { in yield of nuts }\end{array}$ \\
\hline Management (M) (NPK + 5 Kg & +55.5 & +68.0 \\
Neem cake + 1 kg Dolornite) & +70.2 & +23.1 \\
M + Bavistin & +61.5 & +23.7 \\
M + Calixin & +27.4 & +22.2 \\
M + Aureofungin-sol & +70.2 & +20.7 \\
M + Vitavax & +24.2 & +42.9 \\
Bavistin & -0.4 & +64.7 \\
Calixin & +78.6 & +68.8 \\
Aureofungin-sol & +102.6 & -11.5 \\
Vitavax & & \\
\hline
\end{tabular}

Table 4: Detection of MBC in stem cortical tissue samples on the feeding side after different periods of treatment (Anon. 1989)

\begin{tabular}{|l|c|c|c|c|c|}
\hline \multirow{2}{*}{$\begin{array}{c}\text { Amount fed through a } \\
\text { single root }\end{array}$} & $\begin{array}{c}\text { Height of sampling } \\
(\mathrm{m})\end{array}$ & \multicolumn{4}{|c|}{$\begin{array}{c}\text { Presence of MBC in samples taken after } \\
\text { days of treatment }\end{array}$} \\
\cline { 3 - 6 } & 1 & 12 & 20 & 50 & 120 \\
\hline 0.5 g Bavistin & 2 & + & + & - & - \\
& 3 & - & - & - & - \\
& 1 & - & - & - & - \\
5.0 g MBC (10.0 g Bavistin) & 2 & + & + & + & + \\
& 3 & - & + & + & + \\
\hline
\end{tabular}

+ MBC present - MBC absent

Another area of research that is gaining momenturn in the field of stem bleeding disease management is that of biological control. Gowda (1987) studied the in vitro interaction of mycoflora associated with stem bleeding lesions. These lesions harboured potent antagonists like Trichoderma harzianum and $\mathrm{T}$. viride in addition to many other commensals. His study revealed that bark and soil samples collected from neem-cake amended soils yielded a higher percentage of $\mathrm{T}$. harzianum, Aspergillus niger and Penicillium species, all of which exhibited antagonistic reactions towards $T$. paradoxa., Of these, maximum inhibition of T. paradoxa was effected by T. viride (90\%) followed by T. Marzianum (86.6) and A. nige (50\%).

In vivo interaction of these antagonists with T. paradox was studied by inoculating these organisms on detached leaf petioles by Usman (1988). Here Trichoderma caused lysis of the hyphae of $T$. paradoxa either by physical contact or through diffusible compounds. 


\section{Concluding Remarks:}

Currently, biological control studies are given a lot of impetus in this country. Isolation of more fungal and bacterial antagonists, studying their mechanisms of antagonism, and standardizing methods of mass multiplication of the efficient candidates, are important areas under investigation. Standardization of methods of application of these organisms to soil or to the bark is yet another area that is getting our attention. These together with a judicious application of chemicals supplemented with large doses of organic matter and neemcake, besides a well regulated moisture regime in coconut soils, is hopefully the answer to the stem bleeding disease. Radhakrishnan and Potty (1980) have reported from preliminary field observations, that West Coast Tall variety is the most resistant among the indigenous cultivars to this malady.

\section{REFERENCES}

ANON. 1989. CPCRI Annual Report for 1988. pp. 186. CPCRI Kasaragod, Kerala, India.

ANON. 1990. CPCRI Annual Report for 1989-90. 262 p. CPCRI Kasaragod, Kerala, India.

GOWDA, P.V. 1987. In vitro studies on the interaction of antagonistic mycoflora with Thielaviopsis paradoxa, the causal agent of stem bleeding disease. M. Phil. dissertation - Mangalore University, Karnataka, India. 215 p.

Unpublished.

MATHEW AS AND RAMANDAN PL. 1980. Incidence of stem bleeding disease of coconut palm in relation to $\mathrm{pH}$ and electrical conductivity of soils. Journal of Plantation Crops (1): 40-42.

MATHEW J, NAMBIAR KKN, JOSE CT AND ANIL KUMAR 1989. Stem bleeding disease of coconut - A method for indexing the disease severity. Journal of Plantation Crops 17 2): 80-84.

NAGARAJAN M. 1985. Influence of saline environment on the incidence of stem bleeding in coconut (Cocos nucifera L.). Science and Culture 57: 349-351.

NAMBIAR KKN AND SASTRY, K. 1988. Stem bleeding disease of coconut: Current status and approaches for its control. Philippine J. Cocon. Studies 12(1): 30-32.

NAMBIAR, KKN, ANIL KUMAR, SASTRY K AND JOSHI Y. 1989. Seasonal effect on infection by coconut stem bleeding pathogen. Thielaviopsis paradoxa. Current Science 58: (1) 34-35.

NAMBIAR, KKN, JOSHY Y, VENUGOPAL MN AND MOHAN R. C. 1986. Stem bleeding disease of coconut: Reproduction of symptorns by inoculation with Thielaviopsis paradoxa. Journal of Plantation Crops 14 (2): 130-133.

NISHITA NAIK, 1990. Variability and characteristics of different isolates of Thielaviopsis paradoxa pathogen of coconut stem bleeding disease. M. Phil. dissertation submitted to Mangalore University, Karnataka, India 74 - p. Unpublished.

OHLER, J.G. Coconut, tree of life G.A.O. Rome pp446.

PETCH, T. 1906. Disease of the coconut palms. Tropical Agriculturist 27: 489-491.

PETCH, T. 1906. Coconut stem bleeding disease: Tropical Agriculturist 30: 193-194. 
POTTY NN AND RADHAKRISHNAN TC 1978. Stem, bleeding disease of coconut-Nutritional relations. Proc. PLACROSYM - 1: 147-350

RADHAKRISHNAN, T.C. 1987. Symptom expression in stem bleeding disease of coconut in relation to season. Indian Phytopathology 40 100-102.

RADHAKRISHNAN, T.C. 1990. Control of stem bleeding disease of coconut. Indian Coconut Journal 20 9): 13-14.

RADHAKRISHNAN, T.C. \& POTTY NN 1980. Varietal reaction to coconut stem bleeding disease. Agrl. Res. J. Kerala 18(1): 118-119.

SUNDARARAMAN, S. 1922. The coconut bleeding disease. Agric.Res. Inst. Pus. Bull. 127 - 8.p

USMAN, N.M. 1988. Studies on stem bleeding disease of coconut. M. Phil. dissertation submitted to Mangalore University, India. 71 p. Unpublished.

\section{DR. K.K.N. NAMBIAR}

Dr. K. K. N. Nambiar is at present the Head of the Division of Crop Protection of the Central Plantation Crops Research Institute. He obtained his Masters degree in Agriculture in 1960 and worked on racie of coffee of leaf rust under Coffee Board. After obtaining his Ph.D. from the Madras University in 1967, he joined the ICAR service in 1968 working mainly on epiderniology and control of diseases of coconut, arecanut, spices, cashew and on sugarcane. He is presently working on stem bleeding and Ganoderma wilt diseases of coconut.

\section{Dr. ROHINI IYER}

Dr. Rohini Iyer joined the Central Plantation Crops Research Institute in 1978 as Scientist SG in 1978 and worked on field control of rhizome rot disease of ginger. Currently she is working on the mycorrhizal association in coconut and intercrops in a coconut based High Density Multispecies Cropping System (HDMSCS) and on biocontrol of stem bleeding and Ganoderman wilt of coconut. Prior to joining the Institute she was an INSA Fellow on Coprophilous fungi and a CSIR Pool Scientist on BLB of rice. Dr. Iyer earned her Ph.D. in Mycology and Plant Pathology from the Indian Agricultural Research Institute, New Delhi where she worked on certain aspects of the bacteriophages of the Bacterial Leaf Blight Pathogen of rice. 